\title{
The Authority of the Honorary Regional Notary Assembly in Relating to Inspection of Notary of Move of Position Area by Law Enforcement Officer
}

\author{
Ahmad Laduni Arif Rahman \\ Law Faculty of Narotama University \\ St. Arif Rahman Hakim No.51, Klampis Ngasem, Sukolilo, Kota \\ SBY, Jawa Timur 60117 \\ E-mail: ahmadladuniarif@gmail.com \\ Rusdianto Sesung \\ Law Faculty of Narotama University \\ St. Arif Rahman Hakim No.51, Klampis Ngasem, Sukolilo, Kota
}

SBY, Jawa Timur 60117

\begin{abstract}
Implementation authority of the Honorary Regional Notary Assembly in giving approval and/or rejection of a request for approval from law enforcement (Investigator, Public Prosecutor, or Judge)to a Notary who has moved the office area in relation to the deed he / she has made with the criminal case. Cause 2 (two) fundamental questions relating to the authority of the Honorary Regional Notary Assemblyauthorized to grant approval and / or rejection of the application for approvaland the determination of the time limit of no later than 30 (thirty) working days for the Honorary Regional Notary Assembly shall provide the answers.From the results of the research note that based on legislation, authority to grant approval to a Notary who moves to office of the apparatus of law enforcement officersis the jurisdiction of the Honorary Regional Notary Assembly in which the Notary's position is concerned. This means that such provisions shall apply directly to the determination of a maximum 30 (thirty) working day time limit for the Honorary Regional Notary Assemblygiving the answer counted at the receipt of the summoning letter by the law enforcement apparatus.
\end{abstract}

Keywords: Authority of the Honorary Regional Notary Assembly,Inspection of Notary of Move of Position Area, Law Enforcement Official

\section{INTRODUCTION}

The Honorary Notary Assembly established under the provisions of Article 66 and Article 66A of the ActNo. 2 of 2014 on Amendment of The Act. No. 30 of 2004 on Notary officeand following by Regulation of the Minister of Justice and Human Rights No. 7 of 2016 on the Honorary Regional Notary Assembly. That Rule places the Honorary Notary Regional Assembly as an institution having the authority to execution the guidance and supervision of a Notary in performing his / her position of providing legal services to people which concretely 
realized in the form of granting authority to the Honorary Notary Regional Assembly to approval or rejection for of the process judiciary, as the request to take photocopy of Minuta Deed and/or letters attached to minuta deed or Notary Protocol in Notary's depository and Notary's invitation to present in the investigation relating to Deed or Notary Protocol where is in Notary's depository.Establishment of this institution aims to protect the reputation of Notary from Law Enforcement Officials (Investigators, Public Prosecutors or Judges) against the taking of minuda deed and Notary Call. Thus, law enforcers can not directly call Notaries to the judicial process, that they have to go through the approval of theHonorary Notary Regional Assembly.

Historically, under the provisions of Article 66 before amendment, the Regional Supervisory Assembly was the one authorized to give approval or rejection of the request approval for intake the minutadeed and calling Notary that involved criminal cases by law enforcement officials. However, based on the Constitutional Court Decision Number 49 / PUU-X / 2012, as long as the phrase "with the consent of the Regional SupervisorAssembly" in Article 66 paragraph (1) of the Act No. 30 of 2004 on Notary declared contrary to the Constitution of the Republic of Indonesia Year 1945 and has no binding legal forces. However, after the formationof amendment the act, the provision is reorganized in Article 66 and the competent authority of the Honorary Notary Regional Assembly. Substitution institution that authorized to give approval to the application for approval of callings Notary by law enforcement, according to Habib Adjie, does not mean that the guarantee will not happen violations committed by the Notary, it is up to the Notary itself with awareness and full responsibility in his duties respective based on the rule of law applicable and the role of citizens and always report the act of Notary who in carrying out its duties does not accordance with the law. ${ }^{1}$

Therefore, the authority of the Honorary Notary Regional Assemblyin giving approval or rejection of the request for approval of the Law Enforcement officials (Investigator, Public Prosecutor and Judge) include authority are bound.The authority is going on if it has been formulated clearly when, who, and how the authority should be implemented and specified decision should be taken.

Authority (bevoegdheid) of the Honorary Notary Regional Assemblyin giving approval or rejection of the request for approval from law enforcement officers (investigators,

${ }^{1}$ Habib Adjie, (2015), MajelisPengawasNotarisSebagaiPejabat Tata Usaha Negara, RefikaAditama, Bandung, p 3

212 Rusdianto and Ahmad [The Authority of the Honorary Regional Assembly...] 
Volume 1, Issue 2, October 2017

prosecutors and judges) shall be related to the right of transfer/change of position the territory of Notary as regulated in Article 23 and Article 24 and Article 28 through Article 37 of Regulation of the Minister of Justice and Human Rights No. 25 of 2014 on Terms and Procedures for Appointment, Transfer, Dismissal, and Extension of Notary Period that the Notary apply to move the Notary's position in writing to the Minister and under the circumstances, the Minister may transfer a Notary from one jurisdiction to another position.

The authority to giving approval or rejection of the request for approval from Law Enforcement Officials (Investigators, Public Prosecutors and Judges) to Notary who has moved the office area related to the authentic deed itsmade in relation to a criminal case shall at least result in 2 (two) legal issues concerning the authority Honorary Notary Regional Assembly which grants approval or rejection of request approval from Law Enforcement officials to a Notary in a criminal case who has moved the office area. This means that the authority of the approval or rejection of the request for approval shall be the authority of the Honorary Notary Regional Assemblyin which the legal position of the territory of the Notary's last position or authority is owned by the Honorary Notary Regional Assemblyin which the legal status of the territory of the Notary office prior to the transfer of office area.

In addition to the provisions on the limit time determination, give an answer in the form of approval or rejection of the request for approval of the law enforcement officers of the Honorary Notary Assembly, in view of Article 66 paragraph (3) and paragraph (4) of the Law and Regulation of Minister of Justice and Human Rights Number 7 of 2016 on the Honorary Notary Regional Assembly. Examine that the Honorary Notary Assemblywithin 30 (thirty) working days as from the date of receipt of the request for approval as mentioned above obliged to provide an answer to accept or reject the request for approval. As well as in terms of the Honorary Notary Regional Assembly not give an answer within the period referred to above, the assembly considered approve the request. Therefore, based on the legal matters as described, the issue of the authority of the Honorary Notary Regional Assembly give consent to the interests of the legal proceedings against the Notary who moved the territory office and the time of commencement of the 30-day time limit for the Law Enforcement to taken the law process. 


\section{METHOD}

The research conducted by normative juridical, with statute approach, historical approach $^{2}$ and conceptual approach.The legal material in this research are primary and secondary use card system to analysis.

\section{ANALYSIS AND DISCUSSION}

\section{The Authority of the Honorary Regional Notary Assembly in Giving Approval on}

\section{Behalf of The Legal Process to A Notary Who Has Moved the Office Area}

The authority of the Honorary Regional Notary Assembly in giving approval on behalf of the legal process to a notary based on the provisions of Article 66 of the law and subsequently regulated in the Regulation of the Minister of Justice and Human Rights No. 7 of 2016 Honorary Regional Notary assembly and Regulation of the Minister of Justice and Human Rights Number: M.03.Ht.03.10 of 2007 on Taking Deed minuta And Summoning Notary. Article 18 paragraph (1) and paragraph (2) of the Regulation of the Minister of Justice and Human Rights No. 7 of 2016 onHonorary Notary Assembly, stating that the Honorary Regional Notary assembly has the duty to examine the the request by the Investigator, Prosecutor and Judge and give approval or rejection of a request for approval of a Notary's summon to be present in the investigation, prosecution and judicial proceedings. Such authority based on the function of the Honorary Regional Notary Assembly conducting guidance in order to guard the dignity and honor of Notary in performing his profession and to provide protection to Notary in relation to the obligation of Notary to conceal the contents of the Deed.

According to Habib Adjie, the provisions concerning the authority of the Honorary Notary Assembly in terms of approving or rejecting for investigations and judicial processes. Abandonmentof the provision shall the action of the Investigator, Public Prosecutor or Judge be qualified as a violation of the law, and all results of the examination shall temporarily not be continued until the provisions of the regulations done by the Investigator, Prosecutor or Judge. ${ }^{3}$ This relates to the consideration that the Honorary Regional Notary Assembly in execution the duties, has the function of conducting guidance in order to guard the dignity and honor of a Notary in performing the profession of his position and to provide protection

\footnotetext{
2Peter Mahmud Marzuki, (2005), Penelitian Hukum, Jakarta:Kencana Prenada Media Group, p. 113 ${ }^{3}$ Habib Adjie, (2009), Sanksi Perdata Dan Administratif Terhadap Notaris Sebagai Pejabat Publik, Bandung: Refika Aditama, , p. 11.
} 
Volume 1, Issue 2, October 2017

to Notary in relation to the obligation of Notary to conceal the contents of the Deed.

In the general legislation concerning the notary there is no provision that explicitly regulates the authority of the Honorary Regional Notary Assembly on the approval of the legal proceedings to the Notary who moved the position area. This is due to both the law and Regulation of the Minister of Justice and Human Rights No. 25 of 2014 on Terms and Procedures for Appointment, Transfer, Dismissal, and Renewal of Notary Period, and particular the Regulation of the Minister of Justice and Human Rights No. 7 of 2016 Honorary Notary Assembly and Regulation of Minister of Justice and Human Rights Number: M.03.Ht.03.10 Year 2007 About Taking Minuta Deed AndSummon the Notary,does not expressly regulate the Authority of the Honorary Regional Notary Assembly to give approval to the summonthe Notary who moves office area to present in the examination relating to a Notary Deed or Notary Protocol which is deposited in a Notary. The rules apply only to notaries who are still in the jurisdiction of the authority of the Assembly concerned.

Legal issues regarding the uncertainty of the authority of the Honorary Notary Assembly should be authorized to grant approval or rejection of the request for Law Enforcement (Investigator, Prosecutors and Judges) in summoning Notary relates to a deed's made involved the criminal at least can be connected with the regulation of the exercise of authority law enforcement officials either Investigator, Prosecutor and Judge as regulated in Article 7, Article 112 and Article 113, Article 146, Article 159and particular Article 227 of the Act. No. 8 of 1981 on the Criminal Procedure Code (KUHAP). Substantially states that all kinds of notices or summon by the authorities (Investigators, Prosecutors and Judges) at all levels of examination to witnesses, defendants or experts are submitted no later than three days before the prescribed date, or at their last residence.

The regulation related to the determination of the authority of theHonorary Regional Notary Assemblyauthorized to approval or rejection of a law enforcement requestto Notary who moved the office area in relation to the Notarial deed that involvewith the criminal case. This means that the authority shall approve or reject the notary who moved office area is a position of authority Honorary Regional Notary Assembly last of the Notary office area concerned. Thus, the legal basis of authority Honorary Regional Notary to give approvefromrequestsummon the notary who moved the office area by Law Enforcement officialbasedon the Regulation of the Minister of Law and Human Rights No. 7 of 2016, as stated in Article 23 paragraph (1) that the application for approval the summon Notary by the investigator, the prosecutor, or judge to be present in the examination relating to the deed with 
the Chief of the Honorary Regional Notary Assembly in accordance with theNotary area concerned.

Therefore, law enforcement official based on the authority given from the legislation submit the letter of approval to the Honorary Regional Notary Assemblythat the legal status of the Notary concerned, on the requirements and procedures in the Regulation of the Minister of Justice and Human Rights No. 7 of 2016 About the Honorary Notary Assembly.In the provisions of Article 27 of the Regulation of the Minister of Justice and Human Rights No. 7 of 2016 define several terms of summon a Notary by Investigators, Prosecutors or Judges for the purposes of the judicial process in relation to the granting of approbe to the Investigator, Prosecutor or Judge, carried out in terms of:

a. suspicion of a criminal act related to theMinutaDeedand/or Notaries in the depository;

b. have not yet denied the right to sue under the provisions of expiration in the legislation in the field of criminal law;

c. a denial of the signature of one or more parties;

d. suspicion of reduction or addition to the Minutes of Deed; or

e. suspicion the notary made a date of resignation (antidatum).

Thus, it relates to the regulation on execute the authority of the law enforcement official, that the Honorary Regional Notary Assembly has the authority to examine and grant approval/rejection of the request for approval of summonthe Notary who moved the office area to the deed which involve with law enforcement is Honorary Regional Notary Assembly last legal domicile of Notary concerned.

\section{Determination of Time Limit to Begin Counting time limit of 30 Days for Law Enforcement Official to Enforcethe Legal Processes}

Determination of time to begin counting time limit of 30 days for law enforcement to enforce the legal processesto Notary who has moved office area, related withthe authority of the Honorary Regional Notary Assembly last legal domicile of Notary concerned. The legal basis on the Regulation of Minister of Justice and Human Rights No. 7 of 2016 on Honorary Notary Assembly.Determination that time is inseparable from the procedures/work procedures of the Honorary Regional Notary Assembly on the granting of approval or 
Volume 1, Issue 2, October 2017

rejection of the request for approval of the notarial summon by law enforcement official as mention in Regulation of the Minister of Justice and Human Rights No. 7 of 2016 on the Honorary Notary Assembly.Prior to the establishthe Regulation of the Minister of Justice and Human Rights No. 7 of 2016 on the Honorary Notary Assembly, the legal basis of Taking Minuta Deed And summon the Notary submitted by Investigators, Prosecutors and Judge, based on Regulation of Minister of Justice and Human Rights Number: M.03 .Ht.03.10 Year 2007 About Taking Minuta Deed And Notary Call. In accordance with the title of this regulation on the terms and procedures on the taking of minuta deed and summon the Notary.

In the provisions of Articles 14 till 18, Regulation of the Minister of Justice and Human Rights Number: M.03.Ht.03.10 of 2007 substantially states that the Investigator, Prosecutor or Judge for the purposes of the judicial process may summon Notary as a witness, suspect, or the defendant by submitting a written request to the Regional Supervisory Assembly. The copy requested shall be submitted to the Notary by including the reason for the summon of a Notary as a witness, suspect or defendant.The Regional Supervisory Assembly shall give the approval of the Notary's summon if there is a suspicion of a criminal act related to the Deed and/or the letters attached to the minuta deed or Notary Protocol in the Notary's depository, or not to be denied the right to sue under the provisions of expiration in the law in the field of crime. Approval of the Regional Supervisory Assembly shall be granted after hearing the information of the Notary concerned.The Regional Supervisory Assembly shall not give consent to the Investigator, Public Prosecutor or Judge for summonthe Notary as a witness, suspect or defendant in the absence of such provision. The Regional Supervisory Assembly shall be obliged to give consent or not to give written consent within a period no later than 14 days from the receipt of the application letter and if within the period referred to is exceeded then the Regional Supervisory Board shall be considered to have agreed.

Then, with the establishment of Regulation of Minister of Justice and Human Rights No. 7 of 2016 on Honorary Notary Assembly. The regulation concerning the procedure of granting of the Notary Summoning by the Honorary Notary Assembly of request of summon the Notary approve by the Investigator, the Prosecutor and the Judge is explicitly examine in the provisions of Article 20 till Article 26.Substantially the Honorary Regional Notary Assembly shall first held discussion to obtain the decision of the Honorary Regional Notary Assembly, in the case of an examination of the Notary requested by the Investigator, the prosecutor or judge and the approval or rejection of the request for approval of the Notary's notification to be present in the investigation, prosecution, and judicial proceedings relating to 
the Notary's deed or protocol which is deposited in the Notary's depository.

To conduct an examination of a Notary, the Chief of the Honorary Regional Notary Assembly shall form an Examining Council consisting of 3 persons comprising each element of the member of the Honorary Regional Notary Assembly. The Examining Council shall consist of 1 (one) concurrent chairman and 2 (two) members in conducting the examination, the council of Examiners shall be assisted by 1 (one) secretary. Establish the Examining Council shall conducte within 5 (five) working days as from the date of submission the report. Where in this regulation affirm that council authorized to examine and give approval or rejection of request from Investigator, Prosecutor or Judge related to taking photocopies of minuta deeds and letters attached to minuta deed and/or Notary protocol in Notary'sdepository and summon the Notary. That result of examination from councill is report to the Chief of the Honorary Regional Notary Assembly.

That the provisions Article 23 paragraph (1) that the application for approval of Notary by the Investigator summons, the prosecutor, or judge to be present in the examination of the deed was involved with, the Chief of the Honorary Regional Notary Assembly in accordance with the working area concerned. This request is submitted in writing in the Indonesian language and copy submitted to the Notary concerned, and should include at least:

a. notary's name;

b. notary's office address;

c. number of deeds and/or letters attached to a minuta deed or Notary protocol in the Notary's depository; and

d. the principal case is suspicion

The chief of the Honorary Regional Notary Assembly shall give an answer in the form of approval or rejection of the application within a period of 30 (thirty) working days from the date of receipt of the request and if within the period referred to is exceeded, the Regional Notary Council shall considered receive the request for approval.

The Examining Councilon conducting the examination shall have the authority to summon the Notary on the basis of the request of the Investigator, the Prosecutor or the Judge. The summoning of Notary through a letter signed by the Chief of the Honorary Regional Notary Assembly. However, such provision shall be exempted on urgent situation, summons may be made by facsimile and / or electronic mail immediately followed by a 
Volume 1, Issue 2, October 2017

summons letter. Summonthe notary shall made within 5 (five) days prior to the examination. Notary required to attend the summon of the Examining Council and may not be represented, that the case of a Notary being absent after being summoned legally and as of 2 (two) consecutive times, the Examining Council may decide on the request of the Investigator, Prosecutor or Judge.

The Examining Assembly shall give approval or rejection upon hearing the direct statement from the Notary, then shall be set in the minutes of examination. In the event that the Examining Assembly approves the Investigator's, the Public Prosecutor's or the Judge's request, the Notary is required to provide a copy of the minutadeed and / or letter of letter required to submit a copy of the deed and/or letter as mean to minutes submission signed by the Notary and the Investigator, the Public Prosecutor or Judge shall be witnessed by 2 (two) witnesses.

Thus, the determination of counting a time limit of 30 days for law enforcement to enforce the legal processes cannot be separated from the procedures of the Honorary Regional Notary Assemblyto approval or rejection of the requested for approval summon the Notary by investigator, public prosecutor, or the judge that explicitly set in the provisions of Article 20 until Article 26 of the Regulation of the Minister of Justice and Human Rights No. 7 of 2016 from the date of receipt of the request from the Investigator, Prosecutor or Judge and if within the time period referred to is exceeded, the Honorary Regional Notary Assembly considered receiving approval request.

\section{CONCLUSION}

That the Honorary Regional Notary Assembly having the authority to examine and give approval/rejection of the request for the summon of a Notary who moved the office area in relation to the deed has made and involve to the criminal case by the Law Enforcement Officer is the authority of the last Honorary Regional Notary Assembly status of the Notary. And regarding the examining the time to start of the calculation the 30 days time limit for Investigators, Prosecutors or Judges to enforce legal process still based on Regulation of the Minister of Justice and Human Rights No. 7 of 2016 from the date of receipt of the request from the Investigator, Prosecutor or Judge, in case within the period referred to is exceeded, the Honorary Regional Notary Assembly shall considered to have received the request for approval. 


\section{Bibliography}

\section{Books}

Habib Adjie, (2015). Majelis Pengawas Notaris Sebagai Pejabat Tata Usaha Negara, Bandung:Refika Aditama, , (2009), Sanksi Perdata Dan Administratif Terhadap Notaris Sebagai Pejabat Publik, Bandung: Refika Aditama.

Peter Mahmud Marzuki, (2005), Penelitian Hukum, Jakarta :Kencana Prenada Media Group. Safri Nugraha, dkk,(2007).Hukum Administrasi Negara, edisi revisi, Centre For Law and Good Governance Studies (CLGS).

\section{Acts}

Undang-Undang Nomor30 Tahun 2004 Tentang Jabatan Notaris (Lembaran Negara Republik Indonesia Tahun 2004 Nomor117,Tambahan Lembaran Negara Republik Indonesia Nomor 4432);

Undang-Undang Republik Indonesia Nomor 2 Tahun 2014 Tentang Perubahan Atas UndangUndang Nomor 30 Tahun 2004 Tentang Jabatan Notaris, (Lembaran Negara Republic Indonesia Tahu 2014 Nomor 3, Tambahan Lembaran Negara Republik Indonesia Nomor 5491);

Undang-Undang Nomor 30 Tahun 2014 Tentang Administrasi Pemerintahan, (Lembaran Negara Republik Indonesia Tahun 2014 Nomor 292, Tambahan Lembaran Negara Republik Indonesia Nomor 5601);

Peraturan Menteri Hukum Dan Hak Asasi Manusia Republik Indonesia Nomor 7 Tahun 2016 Tentang Majelis Kehormatan Notaris;

Peraturan Menteri Hukum Dan Hak Asasi Manusia Republik Indonesia Nomor 25 Tahun 2014 Tentang Syarat Dan Tata Cara Pengangkatan, Perpindahan, Pemberhentian, Dan Perpanjangan Masa Jabatan Notaris;

Peraturan Menteri Hukum Dan Hak Asasi Manusia Republik Indonesia Nomor 27 Tahun 2016 Tentang Formasi Jabatan Notaris Dan Penentuan Kategori Daerah; 